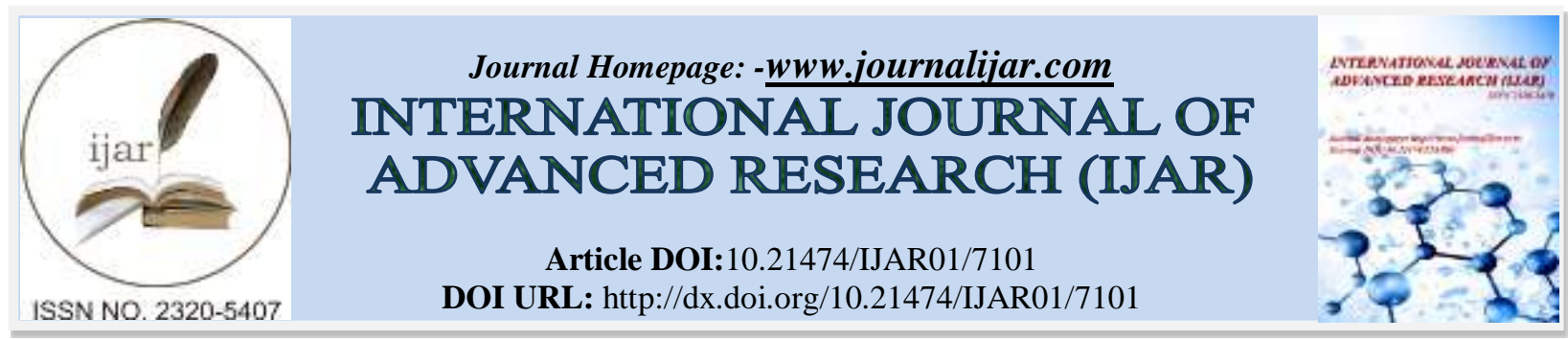

RESEARCH ARTICLE

\title{
ADVANTAGES OF PRACTICING PEER ASSISTED LEARNING AMONG UNDERGRADUATE DENTAL COLLEGES OF BANGLADESH.
}

\section{Dr. A. B. M. Rizwanur Rahman ${ }^{1}$, Dr. Mohammad Faruque ${ }^{2}$, Dr. Sanjida Tasnim ${ }^{3}$, Dr. Md. Mukhlachur} Rahman $^{3}$ Dr. Shirin sultana ${ }^{4}$ and Dr. Raihan Kibria ${ }^{5}$.

1. Assistant Professor and Head, Department of Periodontology \& oral pathology, Dhaka Community Medical College Dental Unit.

2. Professor and Head, Department Department of Dental Anatomy, Dhaka Dental College.

3. Department of Science of Dental Materials, Marks Medical College Dental Unit.

4. Assistant Professor and Head, Department of Conservative Dentistry \& Endodontics, Delta Medical College Dental Unit.

5. Department of Orthodontics, Marks Medical College Dental Unit.

\section{Manuscript Info}

\section{Manuscript History}

Received: 14 March 2018

Final Accepted: 16 April 2018

Published: May 2018

Keywords:-

Peer assisted learning (PAL), student behavior, Concept.

\section{Abstract}

Objective: Peer assisted learning (PAL) is a common feature of medical education. PAL in the clinical setting, a complex learning environment, requires fresh evaluation. Socio-cultural theory is proposed as a means to understand educational interventions in ways that are practical and meaningful.

Methods: This descriptive type of cross sectional study entitled practice of peer assisted learning among students in selected undergraduate dental colleges of Bangladesh was conducted in four Government and four non-Government dental colleges. The objective of this study was to explore the views of teachers and students regarding the benefits of practicing peer assisted learning. Sample size was 437 (407 students and 30 teachers). Data was collected from students with a self-administered semi-structured questionnaire and from dental teachers with in-depth interview schedule. Data was analyzed by using SPSS 19. Most of the students said that PAL method increase their knowledge.

Result: Most of the students said that PAL method increase their knowledge. In the study most of the teacher said that peer assisted learning increase the confidence of the students and clear the conception about the topics. Teachers also said PAL developed good behavior of the students and also developed helping approach to others. This study finding showed that peer assisted learning (PAL) method is very effective in higher education courses.

Conclusion: we should encourage the students and the teachers about the method.

Copy Right, IJAR, 2018,. All rights reserved. 


\section{Introduction:-}

Peer-assisted learning (PAL) as an educational method has been around since Socrates and Plato began questioning one another's ideas in small groups. In recent times, PAL has gained increasing attention across many different healthcare disciplines and educational sectors. Peer assisted learning (PAL) can be defined as People from similar social groupings, who are not professional teachers, helping each other to learn and learning themselves by teaching (Topping 1996). Although peer assisted learning (PAL) is widely used within undergraduate medical and dental education. Reciprocity is the key to adopting the role of teacher and simply transmitting knowledge, the peer assisted learning process enables the peer assisted learning leader to enhance their own learning experience. Educational institutes aim to provide a program for preparing students with appropriate knowledge, skills and attitudes. The training program should enable trainees to act with a high level competency and performance when they encounter the real situations in workplaces (Wadoodi, Crosby, 2004). Therefore it is important that the educational program applies appropriate teaching strategies to reach this goal.

\section{Background:-}

The benefits of Peer Assisted Learning (PAL) are well established with positive effects on examination scores, student satisfaction and personal and professional development reported. Peer assisted learning (PAL) has been defined as "the development of knowledge and skill through active help and support among status equals or matched companions" (Topping 1996). It is this reciprocity of learning among other things that makes PAL such an attractive idea to educationalists. This is particularly true in medical education, where the restrictions on resources have forced teachers to look to creating new educational environments which can be delivered at a lower cost. The benefits associated with PAL, however, are not confined to examination scores.

PAL can assist the institution to meet external expectations for medical graduates to achieve competency and experience in both teaching and assessment, and may help to instill a life-long culture of teaching. PAL can also address specific gaps within the curriculum, providing additional student support in preparation for assessments ( Burgess 2014).

\section{Rationale:-}

In our current dental education system the teacher student ratio is not satisfactory. It is very difficult to make understand the content completely for all the students within limited duration of class. On the other hand one class does not contain same caliber of students. Those students who can't understand the contents fully may consult with their friends or seniors to clarify the contents. It is really helping for them. As result students are not engaged them in coaching and they can save money and time. Similarly, the students who teach others can achieve confidence on that content. But it has some drawbacks which is also my concern. The aim of my research is to explore the merits and demerits \& its impact on students of peer assisted learning.

\section{Objectives:-}

The objective of this study is to find out the advantages and its effect on students of peer assisted learning.

\section{Methods:-}

This descriptive type of cross sectional study entitled practice of peer assisted learning among students in selected undergraduate dental colleges of Bangladesh was conducted in four Government and four non-Government dental colleges. Total 30 teachers and 407 students were included in this study. All teachers included head of the department, senior Lecturer, Lecturer of the every department and all the students in selected undergraduate dental colleges were the study population. Data were collected from dental teachers with in-depth interviews and from dental student. All the data were checked, edited to reduce errors and arranged manually in SPSS 19 version for analysis. The collected data were duly entered, processed and analyzed. Some of the data were presented in the form of tables and graph with self-administered semi structured questionnaire.

\section{Results:-}

Peer assisted learning helps in building concept and comprehension. There is boost in the perceptions of learners in groups regarding the usefulness of their respective sessions in understanding the subject matter of the course, clarifying basic and complex concepts, learning more about the topic and solving previous exam questions. By participating in PAL, tutors are driven to engage, analyze and verbalize what they know, and to realize and address their own knowledge gaps. A highly effective enquiry based learning experience for students is provided through 
peer teaching, where the act of teaching another student involves using knowledge and skills to engage with another student, promoting a deeper engagement with learning.

Table 1:-Distribution of students regarding the benefits of sharing learning with classmate

\begin{tabular}{|c|c|c|c|c|c|c|c|}
\hline $\begin{array}{l}\text { The benefits of } \\
\text { sharing learning }\end{array}$ & $\begin{array}{l}\text { Strongly } \\
\text { Agree } \\
(f \%)\end{array}$ & $\begin{array}{l}\text { Agree } \\
(f \%)\end{array}$ & $\begin{array}{l}\text { Neither } \\
\text { Agree nor } \\
\text { Disagree } \\
(f \%)\end{array}$ & $\begin{array}{l}\text { Disagree } \\
(f \%)\end{array}$ & $\begin{array}{l}\text { Strongly } \\
\text { disagree } \\
(f \%)\end{array}$ & $\begin{array}{l}\text { Mean } \\
\pm \text { SD }\end{array}$ & $\mathrm{CV}$ \\
\hline $\begin{array}{l}\text { It increases students } \\
\text { understanding }(\mathrm{n}=406)\end{array}$ & $266(65.5)$ & $115(28.3)$ & $6(1.5)$ & $15(3.7)$ & $4(1.0)$ & $\begin{array}{l}4.54 \\
0.787\end{array}$ & $17.3 \%$ \\
\hline $\begin{array}{l}\text { It has opportunity to } \\
\text { clarify complex } \\
\text { concepts }(n=404)\end{array}$ & $224(55.4)$ & $155(38.4)$ & $12(3.0)$ & $11(2.7)$ & $2(0.5)$ & $\begin{array}{l}4.46 \\
0.729\end{array}$ & $16.3 \%$ \\
\hline $\begin{array}{l}\text { It increases students' } \\
\text { confidence }(n=407)\end{array}$ & $225(55.3)$ & $115(38.1)$ & $18(4.4)$ & $9(2.2)$ & $0(0.0)$ & $\begin{array}{l}4.46 \\
0.686\end{array}$ & $15.3 \%$ \\
\hline $\begin{array}{l}\text { It increases passing rate } \\
\text { of students }(n=406)\end{array}$ & $184(45.3)$ & 171(42.1) & $38(9.4)$ & $11(2.7)$ & $2(0.5)$ & $\begin{array}{l}4.29 \\
0.785\end{array}$ & $18.3 \%$ \\
\hline $\begin{array}{l}\text { It minimizes } \\
\text { overloading of } \\
\text { memorizing }(n=405)\end{array}$ & $170(42.0)$ & $168(41.5)$ & $44(10.9)$ & $18(4.4)$ & $5(1.2)$ & $\begin{array}{l}4.19 \\
0.886\end{array}$ & $21.1 \%$ \\
\hline $\begin{array}{l}\text { It increases teaching } \\
\text { skills of } \\
\text { students }(n=404)\end{array}$ & $155(38.4)$ & 191(47.3) & $30(7.4)$ & $19(4.7)$ & $9(2.2)$ & $\begin{array}{l}4.15 \\
0.909\end{array}$ & $21.9 \%$ \\
\hline $\begin{array}{l}\text { It decreases the loads } \\
\text { of teachers }(n=405)\end{array}$ & $83(20.5)$ & $175(43.2)$ & $91(22.5)$ & $48(11.9)$ & $8(2.0)$ & $\begin{array}{l}3.68 \\
0.992\end{array}$ & $26.9 \%$ \\
\hline $\begin{array}{l}\text { It reduces the cost of } \\
\text { education }(n=404)\end{array}$ & $83(20.5)$ & $134(32.9)$ & $89(22.0)$ & $57(14.1)$ & $41(10.1)$ & $\begin{array}{l}3.40 \\
1.243\end{array}$ & $36.5 \%$ \\
\hline
\end{tabular}

$* * \mathrm{SD}=$ standard deviation $(\mathrm{SD}) ; \quad \mathrm{CV}=$ Coefficient of variance $(\mathrm{CV})$

Table 1 shows the benefits of sharing learning with classmates. The benefits of sharing were calculated considering strongly disagree as 1 , disagree as 2 , neither agree nor disagree as 3 , agree as 4 and strongly disagree as 5 . In this table we can recognize that the all benefits of peer assisted learning was most effective as their means were above 4 except in case of 'decreases the loads of teachers' and reduces the cost of education' because their means were less than 4 . All the aspects of benefits have moderate coefficient of variance ranged from $15 \%$ to $37 \%$. 


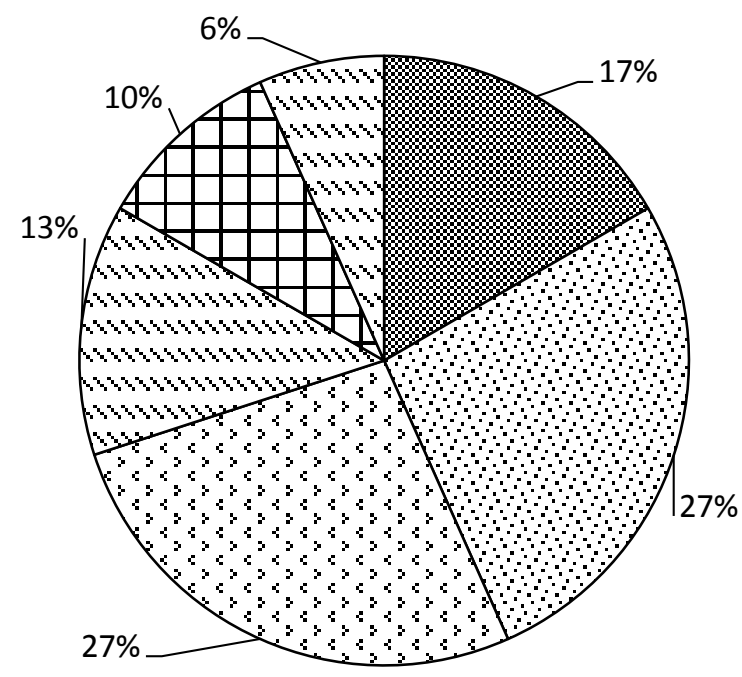

Exchange ideas, knowledge

Conception clear

Increase confidence

Deep learning

Increase understanding level

Curiosity to learn more

\section{Figure 1 Distribution of teachers by their opinion regarding benefits of practice of peer assisted learning}

Figure 1:-Displays Distribution of teachers by their opinion regarding benefits of practice of peer assisted learning. Most of the teachers believed that by practicing peer assisted learning increased confidence and clear the conception about contents of the students. By teachers belief the rate of curiosity to learn more was less assimilated by practicing peer assisted learning.

\section{Discussion:-}

Dental practice is based around contextualizing knowledge and applying it to patients in a clinical situation. In this study we showed that peer assisted learning provides an additional opportunity for the students to achieve this. In addition, with the diverse range of individuals in a community, practitioners know that techniques constantly have to be modified and adapted to the needs of the individuals in a community; practitioners know that techniques constantly have to be modified and adapted to the needs of the individual patient or client. It appeared that the Peer assisted learning helped students with this understanding by providing case scenarios. Peer assisted learning gave students time to practice communication skills through role-playing. Peer assisted learning also helpful for improving the knowledge and skills. It also helped the students to improve their confidence.

All the benefits (mentioned in table-1) of peer assisted learning were most effective as their means were above 4 except in case of 'decreases the loads of teachers' and reduces the cost of education' because their means were less than 4. All the aspects of benefits have moderate coefficient of variance ranged from $15 \%$ to $37 \%$. In Henning's (2008) study we found that students experienced mutual benefits whether they are on the giving or receiving end of PAL interactions. Menezes A. (2016) suggested in his study that by practicing peer assisted learning participants were inspired to engage themselves in teaching activities (as a tutor/teacher) during their medical career.

Regarding benefits of practice of peer assisted learning by the opinion of teachers most of them assumed that by practicing peer assisted learning the confidence and conception about contents of the students was amplified. By teachers faith the frequency of curiosity to learn more was less acquired by practicing peer assisted learning.

\section{Conclusion:-}

Higher education is not an easy process for students, requiring them to learn new material, develop higher order cognitive skills and to become successful. Whereas academic staff are responsible for presenting content and also 
contribute to the development of certain cognitive skills, this study demonstrates, how successful the PAL students can be better equipped than lecturers to help those in their PAL guidance to become expert students. The study findings indicate that the PAL scheme helps students though their study with perceived benefits to both PAL attendees and mentors.

\section{References:-}

1. Burgess et al. BMC Medical Education 2014, 14:115; http://www.biomedcentral.com/1472-6920/14/115

2. Henning, Weidner, Marty, Athletic Training Education Journal; 2008; 3(Jul-Sep):84-90 Oby the National Athletic Trainers' Association, Inc.www.nataej.org

3. Menezes Audrey, Annette Burgess, Antonia J Clarke, Craig Mellis, . Peer-assisted learning in medical school: tutees' perspective, Advances in Medical Education and Practice 18january 2016. 182.160.100.98

4. Topping KJ: The effectiveness of peer tutoring in further and higher education: A typology and review of the literature. Higher Education (Historical Archive) 1996, 32:321-345.

5. Wadoodi, A. and J.R. Crosby, Twelve tips for peer-assisted learning: a classic concept revisited. Med Teach, 2002. 24(3): p. 241-4. 